\title{
効果的な教え方とは何か \\ 一授業の構造に注目して一 \\ What Makes Teaching Effective?: \\ Focusing on Structures in Lesson Planning
}

\section{小玉 博昭 \\ 香港大学博士課程}

\section{要旨}

教育効果の高い授業とそうでない授業とを隔てるものは何か。これまで、教員養成 や教師の成長は経験論で片付けられてきたきらいがあるが、それを明示化できれば、 経験の浅い教師や徒弟制度の恩恵を受けられる環境にない教師には朗報であり、教員 養成にも活用が期待できる。そこで本稿では経験豊富な現職の日本語教師の教案分析 から、教育効果が高いとされる階層的構造で主に文型導入が構成されていたことが明 らかになった。それに対し、教壇に立ったことのない実習生の文型導入では教育効果 が限定的とされる連続的構造が多く観察された。また、現職の教師たちが教育効果の 高い構造について認知しているのか否か、そして、どのように専門的な教える技術を 身に付けてきたのかについて明らかにするため、実習生を含むほかの教師たちが作成 した教案にコメントを付けてもらい、そのコメントも分析対象とした。また、その コメントを含め、授業デザインの詳細を知るため、半構造化インタビューを最後に 実施した。この三つのデータの比較・分析結果を Marton and Saljo (1976)の深い学習と 浅い学習というアプローチ、そして Martensson (2019)の研究授業で得られた視座と 照らし合わせて考察を加えた。この考察から、経験を問わず身に付けることができる 領域、修得にある程度の経験を必要とする領域、そして経験や徒弟制度の枠組みが 必要不可欠な領域の三つに分けられることがわかった。これにより、これまで徒弟 制度や経験論が一括して引き受けていた教師の成長や教員養成といった分野を細 分化し、教師個人でも対応できる部分が示唆された。

キーワード：日本語教育、教師の成長、教員養成、授業の構造、経験論 


\section{効果的な教え方とは何か \\ 一授業の構造に注目して一}

\section{小玉 博昭 \\ 香港大学博士課程}

\section{1.はじめに}

教育に携わり、授業を行っている者であれば、より良い授業を提供したいと考える のは自然なことである。それは日本語教育に従事している者についても然りであり、 経験豊富な教師からまだ経験の浅い駆け出しの教師にも当てはまると思われる。教師 の成長のため、現職の教員も各種の勉強会やワークショップ、授業見学等に参加を するが、良い授業とは一体どんな授業なのだろうか。教育目標を達成できる授業が 良い授業だとすると、達成後にそれは効果的な授業であったと判断される。しかし ながら、他の教員や実習生の授業を見学して、その授業の良し悪しを判断することが ある。本来、教育効果の有無を判断するには教育の前後で評価をし、その対比から 判断をなされるべきであるが、そこまでしている教師はごく僅かであろう。それでは、 何をもって授業の教育効果を判断しているのだろうか。このような判断は教師の豊富 な教育経験に基づくものだと予想されるが、経験の浅い教師や教壇に立ったことの ない実習生などにとって、このような経験に基づく判断は非常に困難な作業になる はずである。逆説的に考えると、この言語化できない経験論で処理されてきた部分を 明示的に説明することができれば、教員養成の大きな助けとなると考えられる。また、 海外における日本語教育の現場では日本語教員の在籍が一名のみということも多く、 自身の専門的知識や技術のブラッシュアップの機会も限定的である。このような環境 下にある教師にも、効果的な授業の明示化に成功すれば、自分の授業を客観的に自己 評価できるようになることが期待できる。本研究では経験豊富な現職の日本語教師の 教案分析を通して、授業デザインの構造に着目して論じる。

\section{2. 先行研究}

\section{1 教師の成長}

日本語教師の成長についての報告や調査があるが、その多くが教師の心理的な部分 に焦点を当てたものや、心構えについてもの（秋田, 1998; 牛窪, 2014; 春原他, 2006） が目立つ。精神面の成長や変化を短期間で行うことは難しく、それを他者が客観的に 確認し、参考にすることは不可能に等しい。そのため、精神面の成長は教師の成長 に不可欠なものと判断できるが、経験が精神面の成長に関わっていることが多く、 こちらも経験論で結論付けられることが多いのではないだろうか。また、言語の 4 技 能別に実践報告が多岐にわたって報告されているが、何らかの原理や理論に基づいて 
いるものは僅かで、また、その教育効果を示寸ものも活動実施後に学習者へのインタ ビューもしくはアンケート調查等を実施し、彼らの感想の確認に留まっている報告が 少なくない。日本語教師を目指寸者向けの指導者や手引きには基本的な授業の手順は 書かれているものの、現職の教師向けには心理・哲学的分野等の抽象性の高いもの、 あるいは各技能別、さらには、ある特定の学習者層に焦点を絞ったものになる傾向が ある。

授業実践の分野では主に日本の初等・中等教育で実施されている研究授業について の研究が注目されている(Stinger \& Hiebert, 2009)。日本の研究授業が注目されて いるのは、日本が理数科目で高い成績を維持し続けていることによる 1 。研究授業は 授業を公開し、多数の同僚や他の学校の教師、研究者等から授業の向上のための意見 を得る機会となる。しかし、研究授業は集合的に授業の教育効果を高めるための システムに関する手法・研究で、個人で行うことは不可能である。さらに、研究授業 は参加する教師の経験をリソースとしているため、やはり経験論の域から出ることは 難しいと考えられる。石井 (2016)も教師の教育実践や専門的な判断力は教室の外で 理論を学んで実践に当てはめるのではなく、実践をしながら反証的に試行し、それを 蓄積していくものだとしている。さらに、実践の蓄積は同僚との間の重層的な共同 関係の下で遂行されていくと補足している。学校教育で行われている研究授業に類似 の機会も日本語教育関連の機関内でも見られることがあり、既に実施している機関も ある。

一方、教育学の視点からは、観察による徒弟制 ${ }^{2}$ (apprenticeship of observation) が 教師の教え方やビリーフに大きな影響を与えているとしている。観察の徒弟制は Lortie (1975)で紹介された概念で、生徒として授業に参加することで刷り込まれて いく教育観や学びに対する姿勢で、それが固定概念として残存し、教師になってから も、自分が受けてきた教育観から抜け出せなくなるというものである。小学校から 大学を卒業して教師になる場合、膨大な時間を生徒として教室で教育活動にさらされ ているため、教師自身が受けてきた教育が自分自身の教育観に与える影響が大きい ことは想像に難くない。観察による徒弟制が良い教師像に影響を与えることも報告 されている(Lortie, 1975; Pajares，1992)が、否定的な影響についても報告されている (Johnson, 1994; Knowles, 1992)。

1 OECD (経済協力開発機構) が実施する学習到達度調查で、2018 年日本は OECD 加盟国中数学 的リテラシー分野で第一位、科学的リテラシー分野で第二位。

https://www.oecd.org/pisa/publications/pisa-2018-results.htm (2020 年 8 月 25 日)

2 和訳は太田（2017）による。 


\section{2 授業の構造}

Saljo（1982)は 90 名に「多様な学習」についての文章（約 3,700 語）を読ませ、そ の後にその文章の内容について被検者にインタビュー調査を行った。その文章の内容 理解の方法は大きく二種類のパターンに分類できると報告している。一つ目は、文章 内で紹介された内容や事例を順次説明するというものである。そして二つ目は文章 全体の大きな枠組みでの内容及びテーマ、即ちここでは多様な学習についてを説明 し、下位分類となる多様な学習に関連するサブテーマとその事例を話すというもので あった。一つ目の読解方法を採った被検者は文章内の個々の事例については「最初 に...があり、その次には...。」というように説明ができるものの、文章全体の主題に ついて回答ができなかったという。Saljo はこの一つ目の理解の方法を連続的構造 (sequential structure) 、二つ目を階層的構造（hierarchical structure）と呼び、後者の ほうが文章についての深い理解が得られたとしている。

Saljo の視座を踏まえ、Chik et al. (2010)は香港の初等教育における中国語の授業で この二つの理解の方法を参考に実験授業を行った。小学二年生の二つのクラスを対象 に、統制群では連続的構造の授業形式を採用し、文章内に出てくる単語を単語リスト を使い、その単語の構成や発音について説明、その後にまた次の単語の説明をすると いう形式の授業を実施した。一方、実験群では、階層的構造をモデルとし、「単語 フレーズ $\rightarrow$ 文 $\rightarrow$ 段落」というように、視点が小から大へと拡大し、授業の目的は新出 の単語を理解させることであったものの、最終的には単語を文章全体中の一要素と して捉えた授業を行った。事前テストでは差がなかったものの、事後テストでは実験 群が好成績を得たと報告している。

Marton (2015)は現象記述学 ${ }^{3}$ (Phenomenography）の立場から、学習すべき対象・ 現象はそれ単体では世界に存在しておらず、必ずそれが存在する文脈上にあるとする が、一度その文脈から切り離して、そして再び文脈に戻す作業をすることで学習は 進むとしている。例えば、虹を理解するためには、虹を構成する七色の光線の一つ 一つを理解している必要がある。しかし、個々の光線を理解しているだけでは虹を 理解するのに十分ではなく、それが集まり、特徵的な形状となって初めて虹という 概念が完成する。この Martonの視点で前述の二つの構造を捉えると、文脈から切り 離した部分（個々の光線）にのみ注目しているのが連続的構造で、学習す心゙き対象を 再び元の文脈（七色の光線が特徴的な形状で一つになる）に戻す作業が含まれている

3 Phenomenography は教育学の分野における質的研究法の一つである。現象記述学という和訳は 小嶋 (2013)による。 
のが階層的構造だと理解できる。つまり、虹を理解させるために、連続的構造で 授業を組み立てると、個々の光線の詳細を次から次へ説明して虹の概念を教ようと 試みる形になるだろう。それに対し、階層的構造の場合は虹の構成要素である七色の 光線が有機的に集まり、虹という一つの全体になっていることを教える姿勢になると 思われる。

\section{3 日本語教育における教案の独自性}

日本語教育では基本的に目標言語を目標言語で教える直接法が一般的で、多くの 日本語教師養成講座もこの方法で教えることを前提に開講されている。直接法を採用 することは他の言語教育にも見られるため珍しいことではないが、英語教育のように 学習者が既に基礎的な学習を終え、簡単な発話ができる状態で授業に参加することは 日本語教育においては稀である。そのため、直接法という枠組みの中で、さらに共通 言語の不在という制限下では教師の使う言語表現も大きく制限を受ける。また、日本 語教育の教案は教える単元のリストや授業の概要を記したシンプルなものではなく、 教師の教育活動に関わる全ての発言、さらに予想される学習者からの反応や返答を 詳細に記述した非常に情報量の多い文書となる。横溝・坂本(2016)においても、日本 語教育の教案に記述す心゙きものとして教師と学習者が言うこと、行うこと、書くこと が挙げられている。このことから、日本語教育で使われる教案は教育指導案という より、むしろ映画や演劇に使われるスクリプトや台本に近いという見方もできる だろう。

台本を読むことで、その作品のストーリーや登場人物の詳細、そして物語の結末も わかるように、日本語教育の教案は実際に授業に参加せずとも、その教師が思い描く 授業を読み取ることができる内容となっている。本研究では、この日本語教育で 使われる教案の特徽を活用し、異なる教師の作成した教案を集め、比較・検証した。

\section{3. 調查}

\section{1 調査の概要}

豊富な教育経験に裏付けられた効果的な授業、もしくはその具体的な手順を明らか にするために以下の調査と分析を行った。

1. 現職日本語教師と実習生の教案の収集と分析

2. 他の教師の教案へのコメントの収集と分析

3. 現職日本語教師へのインタビュー調査 
日本語教育経験 10 年以上の現職日本語教師 4 名（T1-T4）と日本国内の大学で日本 語教育の授業を履修している実習生 1 名(NT)に、日本語教育の現場で広く一般的に 選ばれている初級日本語の教科書の複数の課を教えるという設定で教案を作成して もらった。対象の学習者は香港の大学で日本語を学ぶ大学生とし、各課 2 時間で 教えるという設定をあらかじめ参加協力者に伝え、それ以外の設定や制限については 特に設けなかった。協力者から提出された教案は Saljo (1982) 及び Chik et al. (2010) で報告された連続的構造と階層的構造を枠組みに筆者が分析した。教案分析終了後は、 参加協力者内に教案を配布し、自分以外が作成した教案にコメントをつけてもらった。 その際、各教案の作成者の情報は一切伝えず、それぞれの教師が付け加えたコメント 内容も分析の対象とした。インタビュー調査は半構造化インタビューで、基本的に オンラインの文字チャットを用い、参加協力者とのやり取りは直ちに文字化された データとして保存し、これも本調査のデータ収集の一部とした。教案についての コメントとインタビュー調査の目的は、現職教師の教える技術の成長が何らかの理論 的枠組みや原則に沿ったものではなく、経験をリソースとしてなされているという

ことの検証である。

表 1 : 参加協力者リスト

\begin{tabular}{|c|c|c|}
\hline 教師 & 教育歴 & 養成講座・資格取得 \\
\hline $\mathrm{T} 1$ & 10 年以上 & 日本 \\
\hline $\mathrm{T} 2$ & 20 年 & 日本 \\
\hline $\mathrm{T} 3$ & 13 年 & 日本 \\
\hline $\mathrm{T} 4$ & 10 年以上 & 日本 \\
\hline $\mathrm{NT}$ & なし (実習を除く $)$ & 日本 \\
\hline
\end{tabular}

\section{2 教案分析の結果}

経験豊富な教師の教案は教師と学習者のやり取りが詳細に記述されており、活動と その意図が明解であった。授業の展開も基本的には導入、パターンプラクティス、 活動と統一されており、スムーズに流れるように進んでいくもので構成されていた。 導入部分で顕著に階層的構造が見られるものとして、T3 の比較表現の導入を挙げたい。 比較表現である「A コーラを例に導入するというものである。まず、二者間の比較である「A だ」を導入後に復習も兼礼てコーラの $\mathrm{S} ・ \mathrm{M} ・ \mathrm{~L}$ サイズのイラストを提示、 $\mathrm{S} ・ \mathrm{M}$ サイズ間、 $\mathrm{M} ・ \mathrm{~L}$ サイズ間で比較させる。そしてその後に、 $\mathrm{S}$ サイズが一番小さい 
ので「S サイズがいちばん小さいです」と導入文型である三者以上の比較で使われる 表現が導入される。この一連の導入の流れを構造という視点で捉えると以下のように まとめられる。

\section{図 $1:$ T3 の比較の授業の構造}

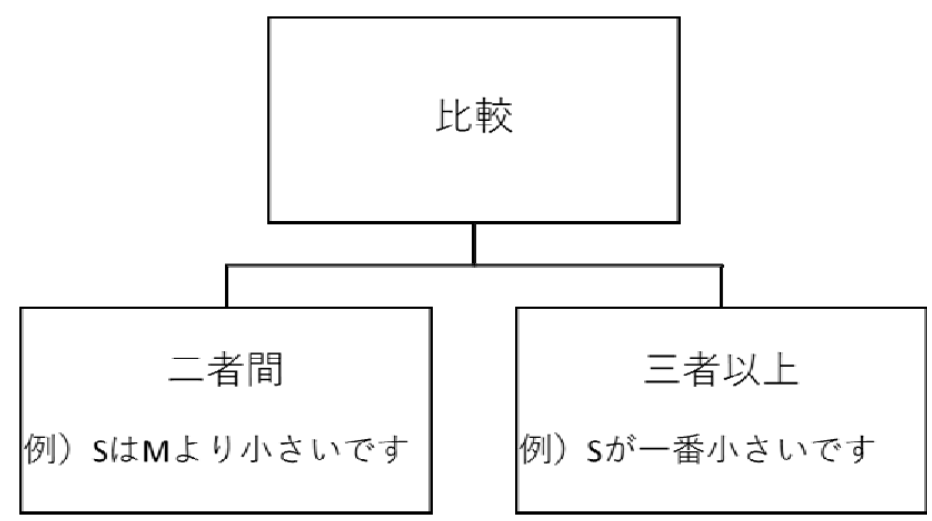

図のように比較という主題が比較対象物の数量により二つの下位分類に分けられ ている。この構造においては主題を理解するために下位分類の二つのサブテーマを 理解しなければならず、また、この二つのサブテーマも主題を通してつながっており、 主題を構成する重要な要素となっている。従って、この構造は階層的であると言える。

一方、実習生の導入ではこの二つの比較表現を個別に扱っており、導入文も北海道 と九州の面積、日本と中国の人口の比較等を二者間の比較表現に、三者以上では一年 で最も暑い月、日本料理で一番好きなもの等を例にそれぞれの文型の導入を試みて いる。この授業の流れを以下の図にまとめる。

\section{図 $2: N T$ の比較の授業の構造}

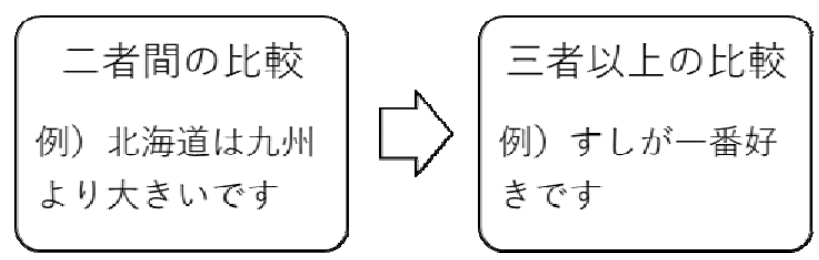

このように実習生の導入では、文型提示の後、その文型の例が挙げられ、その後は 次の導入文型の文型提示とその例が紹介されるという直線的な関係になっているこ とがわかる。この関係では個々の導入文型については理解が容易いと思われるが、 
この二つの文型の関係性が不明確で主題が明らかになっていない。そのため、この 授業の後に学習者に授業の内容について質問しても、学習項目を順を追って説明 できると思われるが、授業全体として何を学んだのか回答するのに困難が生じるで あろう。このように、個々の要素の直前もしくは直後にのみ関連がある関係は、Saljo (1982)の連続的構造と一致する。

\section{3 他者教案へのコメントの分析結果}

場面提示の方法、単語の選び方、活動の量やコミュニケーションとして自然か否か 等、多くの部分についてのコメントが寄せられた。直接法で授業が実施されるためか、 どの教師も使われる表現が既習・未習であるかについて目を光らせている印象が強く 残った。一方、主に実習生の教案に授業の構成の練り直しを求めるコメントが多く

「これでは学習者は理解できない」のように授業の根幹に関わる指摘がしばしば観察 された。しかし、学習者が理解できないと思われる具体的な理由や論拠に言及して いるものはほとんど見られなかったため、インタビュー調査の質問項目に追加した。

\section{4 インタビュ一調査結果}

インタビュー調査では主に以下の点についての回答を本研究の分析対象とした。

1. 教える技能の修得と向上のための方法

2. 実習生の教案について

教える技能については、日本語教師として教壇に上がる前には全員が日本国内の 養成講座もしくは大学の主・副専攻で学んだということであった。全員に共通して いたことは、やはり直接法で授業をするという前提でトレーニングを積んできたと いうことで、単語レベルで媒介語を使うことはあっても、すべての授業を媒介語で 行ったことがあると答えた教師はいなかった。授業を担当するようになってから、 日本語教師としての専門知識や技能の向上には勤務先での授業見学、勉強会への出席、 関連団体のワークショップに参加する等が挙げられた。現行の教師教育（養成講座も 含む) や教える技能を高める方法及び実習生の教案については以下の回答が得られた。 
表 2 : インタビューの回答

\begin{tabular}{|c|c|c|}
\hline 教師 & 教える技能の修得・向上方法 & 実習生の教案 \\
\hline $\mathrm{T} 1$ & $\begin{array}{l}\text { ・自分がいいと思った先生方の } \\
\text { 教授法を参考にしています。 }\end{array}$ & $\begin{array}{l}\text { • ちょっと唐突に未習語彙や文型 } \\
\text { などが導入されている印象を } \\
\text { うけました。学習者がスムーズに } \\
\text { ついてこられるか疑問です。 }\end{array}$ \\
\hline $\mathrm{T} 2$ & $\begin{array}{l}\text { • 徒弟制度のような感じですね。 } \\
\text { ○○式で教えられない教師は } \\
\text { 初級の担当ができません。 }\end{array}$ & $\begin{array}{l}\text { • ちょっと状況を広げすぎていたり、 } \\
\text { 練習の順番が逆だったり。 } \\
\text { 基本的な練習があまりないうちに、 } \\
\text { 練習が進んでいるようで、学生は } \\
\text { 滑らかに言えないのでは? }\end{array}$ \\
\hline $\mathrm{T} 3$ & $\begin{array}{l}\text { ・養成講座で習ったことと、先輩 } \\
\text { からのアドバイスを参考にし } \\
\text { ています。あとは、指導書です } \\
\text { ね。 }\end{array}$ & $\begin{array}{l}\text { ・文型を導入することで精一杯な } \\
\text { 感じで、学生の文法の意味の理解は } \\
\text { 薄くなるのではないかなと } \\
\text { 感じました。 }\end{array}$ \\
\hline $\mathrm{T} 4$ & $\begin{array}{l}\text { ・養成というよりは訓練に近い } \\
\text { 感じでした。 } \\
\text { まるで「未習項目狩り」の } \\
\text { ようなところがありますね。 }\end{array}$ & $\begin{array}{l}\text { ・導入文型を使った表現を学習者が } \\
\text { 言いたくなるような場面設定を } \\
\text { 与えないで、すべて教師が言って } \\
\text { しまっている。 }\end{array}$ \\
\hline
\end{tabular}

T2 の回答から T2 が修了した養成講座にはその機関独自の教授法があり、それを 徹底的に身に付けさせられたことが顕著に読み取れ、T3 の回答からは養成講座修了 後も周囲の教師からアドバイスを得る機会があることを示している。ほかの教師に ついても同様で、教師として教壇に上がる以前から、そして以後も何らかの形で徒弟 制度的な枠組みに組み込まれ、その枠組みの中で自身の専門技能を鍛錬する機会を 得ているようだ。また、T4 の発言にある通り、教えていない要素の使用を厳しく 制限する風潮があることがわかる。

実習生の教案に関して、さらに深く、なぜその指摘箇所が学習者の理解を妨げて いるのかについて質問すると、未習語彙が多いと焦点がずれる等の回答があり、実際 に教師自身の失敗経験から得られたアドバイスだったことが明らかになった。また、 指摘箇所の改善のための手順や代替え案について非常に明確で詳細なアドバイスを 聞くことができた。 
インタビュー調査からはやはり調査参加者で現職の教師の専門技術の修得・成長に は教師自身が積んできた教育経験はもちろんのこと、他者の経験もリソースとして 活用していることがわかった。

\section{4. まとめと考察}

教案分析により、現職の教師の教案、特に導入部分は階層的構造で構成されている ことが多いのに対し、実習生の教案では連続的構造がしばしば観察された。しかし ながら、現職教師の教案のすべての導入部分が階層的構造になっていたわけではなく、 一部連続的構造も見られた。これは実習生についても同じで、すべてが連続的構造で あったということではなく、階層的構造になっている箇所もいくつか見られた。興味 深いことに、現職の教師、実習生、どちらの教案でも、連続的構造で設計された部分 には改善を勧めるコメントが目立ち、階層的な部分にはポジティブなコメントがつけ られるという傾向があった。このことから、経験豊富な教師は階層的構造で練られて いる部分を肯定的に捉えており、かつ、その判断が教育経験によるものだということ を示唆している。また、この点から本稿の調査において階層的構造の効果を帰納的 に捉えることができたと判断できる。さらに、教案へのコメント及びインタビュー 調査から、現職の日本語教師の専門的知識や技術は個人もしくは集合的経験が得 られるある種の徒弟制度的枠組み内で成長することがわかり、これは石井 (2016) と 合致する。しかし、前述のように、海外の日本語教育の現場ではこのような環境に ないところも多く、経験の浅い教師には参照とすべき経験が十分に積みあがってい ないことから、経験に頼らない何らかの指標をもって自分の授業の教育効果を客観的 に判断し、改善していかなければならない。本稿で検証したように構造に着目する ことで、経験のある教師はもちろん、そうでない教師にも授業、特に導入部分に おいて、その展開の構成が階層的になっているか否かである程度の教育効果の判断が 期待できる。

この構造が階層的か連続的かという視点は、Marton and Saljo (1976)の深い学習 (deep learning) と浅い学習（surface learning）という観点からも説明ができる。深い 学習では主に理解に重きを置き、関連知識や自身の過去の経験とをつなげたり、その 内容の構造を明らかにしようとする姿勢であるのに対し、浅い学習では暗記が中心と なり、学習を達成すべきタスクの一つと捉えているため、文脈の理解といったタスク 達成とは直接関係のない部分にまで学習が及ばないとしている。そのため、Saljo (1982)での実験でタスクの理解の方法が階層的、連続的構造であった被検者の学習 はそれぞれ深い学習と浅い学習であったと言えよう。教師は学習者の深い学習を 
サポートするための授業デザインをすべきだ(Biggs，1999)とし、学習者や学習者の 学習のゴールから授業設計をすることが深い学習を進められる環境づくりとなり、 それ故、深い学習をモデルとした教育は学習者中心と考えられる。深い学習に関連 した教師の役割として Marton and Booth (1997)は教師は学習者が既にもっている知識 とこれから教える新しい知識を関連付けることによって、深い学習が進むようにする 必要があるとしている。この Marton and Booth の視座は授業設計をする上で重要で あると同時に、経験の浅い教師の限界も历めかしている。教えるべき単元の知識は 指導書や教科書に記載されているので明確であるが、学習者が既に持っている知識や 理解を把握するには経験を要するためである。

教師が持つべき知識の変容について Martensson (2019)を参考にすると、学習者に ついての理解の扱われ方が整理できる。 Martensson は Shulman (1987)の PCK (Pedagogical Content Knowledge/教育に関する専門知識）を三つに分類した Bell et al., (2008)の KCC (Knowledge of Content and Curriculum/単元とカリキュラムに関する専門 知識)、KCT (Knowledge of Content and Teaching/単元と教え方に関する専門知識)、KCS (Knowledge of Content and Student/単元と学習者に関する専門知識)という教師の専門 知識が研究授業の一種を通して変容していく様子を報告している。Martensson による と、研究授業のサイクルを重ねるにつれ、教師のフォーカスが当初の教える内容 （KCC）重視から、教え方（KCT）、そして最終的には学習者の理解の仕方や既有 知識（KCS）を鑑みて授業を設計するようになったという。また、この三つの概念が 重なり合う部分にこそ、真に教師が保持すべき知識があると結論付けている。この 三つの概念を本研究に参加した現職の教師たちが実習生に付けたコメントの内容と 結ぶ付けて考えると、Martenssonの結論と共通する。そのため、「教えること」とは KCC もしくは KCT、そして「学習者の理解」は KCS の範疇であると考えられる。 特に T3 は実習生に「教えることに精一杯で学生の理解は薄くなるのではないか」と いうコメントをしており、また、コメントによく見られた「これでは学生はわから ない」という指摘も、まさに学習者の理解を重視する KCS に関連するものである。

本研究から教案を作る段階で構造を考慮に入れることで、一定の教育効果の向上が 期待できることが示唆されたが、同時に経験論で説明できる部分とできない部分との 境界線が濃くなったという見方もできるのではないだろうか。Ball et al., (2008)の三つ の概念を参考にすると、KCC は経験の浅い教師ないしは実習生でも個人で身に付け ることが可能な領域、そして KCT 内のどこかにこの境界線が存在し、KCS について は完全に経験がなければ会得が不可能であることがわかる。本研究で扱われる授業の 
構造については、客観的に観察ができることから、KCT に属し、かつ経験や他者と の関わり合いを要しない。このことから、これまではこの三つの知識を徒弟制度の 中で身に付けるという、いわば徒弟制度に依存した考え方から、経験がない個人でも 対応できる部分、経験があればある程度個人でも対応できる部分、そして経験のある 他者もしくはその集団が必要な部分に分業化できることが期待できる。この分業化は 前述のように、周囲に同僚がいない場合や徒弟制度が機能していない機関で教えて いる教師には有益となり、また、教員養成の仕組みも効率化が期待できるのではない だろうか。

\section{5. 今後の課題}

本研究の特徴は実際の授業ではなく、教案を分析対象とし、教案及びインタビュー から得られたデータを教育学の分野で報告されている先行研究や理論を参照しなが ら考察したことにある。構造に注目した教案分析では、主に文型の導入部分を抜き出 して分析対象とした。しかし、実際の日本語の授業では文型導入だけでなく、読解、 会話、作文など多岐にわたる授業が用意されている。この構造が話す・書く等の授業 ではどのように構成されるのかについては本研究では明らかになっていない。また、 調査の参加協力者の数のバランスが取れていなかった。これは調査の目的が経験 豊富な教師の教案から効果的な技法を抜き出すことに起因するが、より説得力のある 議論にするためには実習生も現職の教師と同数にする必要があっただろう。これら 分析対象の拡大と調査方法を主な改善点とし、今後の課題としたい。 


\section{参考文献}

秋田喜代美(1998)「実践の創造と同僚関係」佐伯胖ほか編『教師像の再構築』(岩波講座 6), 岩波 書店

石井英真(2016)「授業の構想力を高める教師の実践研究の方法論」『教育方法の探究』19 号, 11-21 牛窪隆太(2015)「日本語教育における『教師の成長』の批判的再検討一自己成長論から逸脱の場 としての『同僚性』構築へ」『言語文化教育研究』13-26

太田拓紀(2017)「『観察による徒弟制』と教員養成における実践の問題」『滋賀大学教育学部附属 教育実践総合センター紀要』25 巻 93-99

小嶋李輝(2013)「概念主義と学習者現実の理論的基礎付け一Polanyi の理想に求める学習の主観性 研究の展望」『学校教育学研究紀要』6 号, 19-33

春原憲一郎・横溝紳一郎(2006)『日本語教師の成長と自己研鑽一新たな教師研修ストラテジーの 可能性をめざして』凡人社

横溝紳一郎・坂本正(2016)『日本語教師の 7 つ道具シリーズプラス教案の作り方編』アルク

Ball, D.L., Thames, M.H. and Phelps, G. (2008), Content Knowledge for Teaching: What Makes it

Special?, Journal for Teacher Education, 59 (5), 389-407.

Biggs, J. (1999). What the Student Does: Teaching for Enhanced Learning. Higher Education Research \& Development, 18(1), 57-75.

Chik P. P. M. \& Marton, F. (2010). Chinese pedagogy and a pedagogy for Chinese. In F. Marton, S. K. Tse $\&$ W. M. Cheung (Eds.), On the Learning of Chinese (pp. 9-30). Rotterdam, The Netherlands: Sense.

Johnson, K. E. (1994). The Emerging Beliefs and Instructional Practices of Preservice English as a Second Language Teacher'. Teaching and Teacher Education 10(4), 439-452.

Knowles, J.G. (1992). Models for Understanding Pre-service and Beginning Teachers' Biography. In Goodson, I.F. (Ed.) Studying Teachers' Lives. Routledge.

Lortie, D. (1975). Schoolteacher: A Sociological Study. London: University of Chicago Press.

Martensson, P. (2019). Learning to See Distinctions through Learning Studies: Critical Aspects as an Example of Pedagogical Content Knowledge. International Journal for Lesson and Learning Studies, 8(3), 196-211.

Marton, F. (2015). Necessary Conditions of Learning. Routledge, New York.

Marton, F., \& Booth, S. (1997). Learning and Awareness. Lawrence Erlbaum.

Marton, F. \& Saljo, R. (1976). On Qualitative Differences on Learning: I - Outcome and Process. British Journal of Educational Psychology, 46, 4-11.

Pajares, F. (1992). Teachers' Beliefs and Educational Research: Cleaning up a Messy Construct. Review of Educational Research, 62, 307-332.

Saljo, R. (1982). Learning and Understanding: A study of Differences in Constructing Meaning from a Text. Gothenburg, Sweden: Acta Universitatis Gothoburgensis.

Shulman, L.S. (1987), Knowledge and Teaching: Foundations of the New Reform, Harvard Educational Review, 57(1), 1-22.

Stigler, J. W. \& Hiebert, J. (2009). The Teaching Gap: Best Ideas from the World's Teachers for Improving Education in the Classroom. New York, NY: Free Press. 